\title{
Penyuluhan Pembuatan Amoniasi Jerami Padi Pada Kelompok Tani Terus Jaya Dusun Cunil Desa Pegalongan Kecamatan Patikraja
}

\author{
Siti Rahmawati Zulaikhah', Farida Rizqi Fauziah², Bambang Rijanto Japutra ${ }^{3}$ \\ 1,2,3Prodi Peternakan Fakultas Saintek UNU Purwokerto \\ rahwatidjunaidi0@gmail.com ${ }^{1}$, fauziah.zia49@gmail.com² ${ }^{2}$, brj.aprica@gmail.com ${ }^{3}$
}

\begin{abstract}
Farmer groups Terus Jaya in the hamlet of Cunil, Pegalongan Village, Patikraja District, Banyumas, Central Java. The Pegalongan Village area has a large portion of paddy fields, where almost $50 \%$ is dominated by paddy fields, so that at the time of the rice harvest, rice straw is widely available. During the dry season, members of the Terus Jaya Farmer group have difficulty finding food, so there needs to be an effort to prepare feed during the dry season. Making ammoniation of straw is one solution to the problem. The method used in this extension is the transfer of knowledge and technology as well as practice or demonstration of making ammoniation straw. This activity is carried out through several stages, namely socialization about cattle / goat farming, animal feed and making ammoniation straw. This activity was responded positively and enthusiastically by group members and succeeded in providing an understanding of the solution to feeding difficulties in the dry season.
\end{abstract}

Keywords: Rice Straw Ammoniation; Farmers Group; Socialization

\begin{abstract}
Abstrak
Kelompok tani Terus Jaya berada di Dusun Cunil Desa Pegalongan Kecamatan Patikraja, Banyumas, Jawa Tengah. Wilayah Desa Pegalongan memiliki bagian wilayah sawah yang luas, dimana hampir 50\% didominasi oleh sawah, sehingga pada saat panen padi, banyak tersedia jerami padi. Pada saat musim kemarau, anggota kelompok Tani Terus Jaya ini mengalami kesulitan mencari pakan, sehingga perlu adanya usaha untuk mempersiapkan pakan pada saat musim kemarau. Pembuatan amoniasi jerami merupakan salah satu solusi dalam masalah tersebut. Metode yang dilakukan dalam penyuluhan ini adalah transfer ilmu dan teknologi serta praktek atau demonstrasi pembuatan amoniasi jerami. Kegiatan ini dilakukan melalui beberapa tahapan, yaitu sosialisasi tentang peternakan sapi/kambing, pakan ternak dan pembuatan amoniasi jerami. Kegiatan ini direspon positif dan antusias oleh anggota kelompok dan berhasil memberikan pemahaman tentang solusi kesulitan pakan di musim kemarau.
\end{abstract}

Kata Kunci: Amoniasi Jerami; Kelompok Tani; Penyuluhan 


\section{Pendahuluan}

Peternakan merupakan sektor pertanian yang sangat berguna dalam upaya peningkatan gizi masyarakat Indonesia. Setiap tahun penduduk Indonesia mengalami peningkatan jumlah penduduk, hal tersebut menyebabkan penambahan jumlah makanan (olahan daging) juga meningkat. Oleh karena itu salah satu cara yang dilakukan untuk memenuhi kebutuhan tersebut adalah dengan memberikan ketersediaan pakan yang cukup bagi ternak. Salah satu cara yang dapat dilakukan adalah dengan memberikan ternak kualitas pakan yang baik dan selalu tersedia sumber pakan ternak secara berkesinambungan.

Jerami padi adalah suatu limbah pertanian yang sangat mudah didapat bahkan ketika musim panen jumlah jerami padi akan melimpah. Melimpahnya jumlah jerami dan keterbatasan jumlah pakan yang diberikan pada ternak ruminansia pada musim kemarau membuat beberapa pihak memanfaatkan jerami sebagai pakan ternak. Jerami padi memiliki kandungan mineral yang cukup lengkap seperti phosphorus, potassium, zink, sulphur, silicon, magnesium, silicon, iron, manganese, copper, dan boron.

Pada umumnya peternak di desa Pegalongan kesulitan dalam mendapatkan pakan ternak di musim kemarau. Padahal Desa Pegalongan mempunyai sumber daya alam yang bagus, yaitu pada saat panen padi akan menghasilkan banyak jerami padi, tetapi masyarakat belum mampu memanfaatkan potensi alam tersebut untuk mengatasi masalah pakan ternak pada saat musim kemarau. Salah satu cara penanggulangan yang dapat dilakukan adalah dengan memberikan pakan ternak berupa amoniasi jerami padi.

Luas lahan Desa Pegalongan 50\% adalah lahan pertanian. Oleh karena itu sebagian besar penduduk desa Pegalongan berprofesi sebagai petani. Banyaknya lahan sawah mengakibatkan melimpahnya jumlah jerami padi ketika musim panen. Jerami padi adalah bagian batang tumbuh yang setelah selesai dipanen bulir-bulir buah bersama atau tidak dengan tangkainya dikurangi dengan akar dan bagian yang tertinggal setelah disabit (Suyitno, 2006).

Jerami padi mempunyai kandungan protein 3,5-4,5\%, lemak 1,4-1,75, sk 31,546,5\%, abu 19,9-22,9\%, kalsium 0,19\%, fosfor $0,1 \%$, dan BETN 27,8-39,9\% (SUGAMA \& BUDIARI, 2012). Rendahnya kandungan nutrisi pada jerami padi maka pemberian pakan jerami padi harus dilakukan dengan teknologi amoniasi, hal ini dikarenakan jerami yang belum diamoniasi memiliki beberapa kekurangan yaitu kandungan protein rendah, serat kasar tinggi dan kecernaan rendah (Sriyani, Ariana, Oka, \& Utami, 2016). Teknologi amoniasi jerami padi dapat mengubah tekstur jerami yang pada awalnya keras menjadi lunak, meningkatkan kadar protein, bahan organik dan konsumsi bahan kering serta meningkatkan nutrien tercerna. Menurut Bata (2008) dalam (Kleden \& Nenobais, 2018), kandungan protein kasar jerami padi setelah amoniasi sebesar 8,105\% sedangkan yang diamoniasi dan ditambah tetes tebu memiliki kandungan protein sebesar 10,122\%. Oleh karena itu jerami padi dapat dimanfaatkan sebagai sumberdaya pakan yang potensial terutama pada musim kemarau.

Kelompok tani Terus Jaya berada di Dusun Cunil Desa Pegalongan Kecamatan Patikraja, Banyumas, Jawa Tengah. Letak wilayah Desa Pegalongan adalah $8 \mathrm{~km}$ sebelah selatan Purwokerto atau sebelah timur Desa Patikraja. Kelompok tani Terus Jaya ini beranggotakan 20 orang yang hampir semuanya berprofesi sebagai petani/peternak, kelompok ini masih aktif dan diketuai oleh bapak Suparto. Ternak yang dipelihara oleh anggota kelompok ini adalah sapi, kambing dan domba.

Wilayah Desa Pegalongan memiliki bagian wilayah sawah yang luas, dimana hampir $50 \%$ didominasi oleh sawah. Struktur tanah desa Pegalongan adalah tanah liat/lempung. Wilayah ini berupa 
ladang atau bekas hutan yang mana banyak ditanam pohon trembesi, pohon jati, pohon waru, dan lain-lain. Alasan kami memilih wilayah tersebut adalah: pertama, sebagaian besar anggota kelompok tani Terus Jaya tidak mengetahui mengenai teknologi amoniasi jerami padi; kedua, anggota kelompok mengalami kesulitan pemenuhan kebutuhan pakan pada musim kemarau; ketiga, sebagian besar anggota kelompok hanya berprofesi sebagai petani tanpa ada usaha yang lain. Sehingga perlu diberi informasi yang lebih mendalam untuk meningkatkan usahanya.

\section{Pelaksanaan dan Metode}

Kegiatan pengabdian ini diawali dengan melakukan koordinasi bersama kelompok tani mitra, yang diikuti dengan penyusunan materi yang akan diberikan. Selanjutnya dilakukan sosialisasi program.

Pelaksanaan kegiatan PKM ini menggunakan Metode Kaji Tindak yaitu metode yang dilaksanakan dengan cara: a) ceramah tentang peternakan sapi/kambing/domba serta jenis-jenis pakan, dan proses pembuatan pakan. b) ceramah tentang amoniasi jerami padi yang meliputi manfaat, kandungan dan cara pembuatan. c) demonstrasi kepada khalayak sasaran tempat pelaksanaan program melakukan kegiatan tentang pembuatan amoniasi jerami padi.

Bahan yang digunakan untuk melakukan amoniasi jerami padi meliputi: jerami padi, urea, dan air.

Proses pembuatan jerami padi secara rinci mencakup beberapa tahapan, yaitu:

1. Timbang jerami sesuai kebutuhan kemudian dipotong-potong dengan ukuran kurang lebih $10 \mathrm{~cm}$.

2. Timbang urea sebanyak $6 \%$ dari bobot jerami padi, sediakan air bersih sebanding dengan jumlah jerami padi. Dari jumlah tersebut 30\% digunakan untuk melarutkan urea yang sudah ditimbang.

3. Menyiapkan wadah plastik sebagai tempat jerami padi.
4. Masukkan jerami padi yang sudah dipotong-potong kedalam plastik sehingga membentuk lapisan. Setelah itu semprotkan lapisan jerami padi dengan larutan urea secara merata.

5. Setelah penumpukan jerami padi selesai, ikat plastik dengan kencang sehingga hampa udara. Diamkan selama 21-30 hari.

Tahapan dalam pelaksanaan PKM ini adalah sebagai berikut:

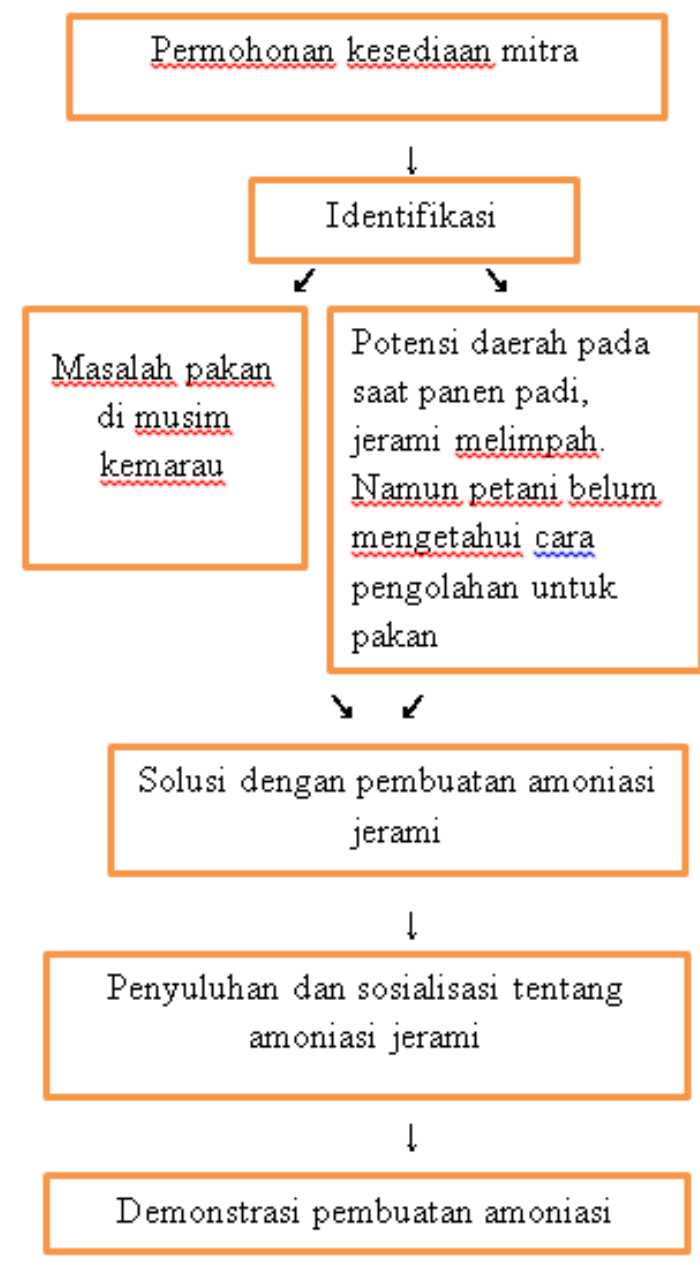

Gambar 1. Tahapan Pelaksanaan PKM

\section{Hasil dan Pembahasan}

\section{Pelaksanaan Kegiatan Penyuluhan dan Demonstrasi}

Kegiatan yang dilakukan saat PKM ini adalah penyuluhan dan demonstrasi yang diikuti oleh seluruh anggota kelompok tani dan mahasiswa Program Studi Peternakan, Fakultas Sains dan 
Teknologi, Universitas Nahdlatul Ulama Purwokerto.. Pelaksanaannya pada tanggal 25 Agustus 2018 pukul 15.00 WIB sampai selesai. Kegiatan ini dilakukan untuk meningkatkan pengetahuan dan motivasi bagi petani. Materi penyuluhan antara lain: a. Peternakan sapi serta jenis-jenis pakan, dan proses pembuatan pakan; b. Penyuluhan amoniasi jerami padi yang meliputi manfaat, kandungan dan cara pembuatan.

Jerami merupakan salah satu limbah pertanian yang banyak terdapat dipedesaan. Melimpahnya jumlah jerami memberikan alternatif untuk melakukan amoniasi pada jerami padi. Amoniasi merupakan suatu proses perlakuan terhadap bahan pakan limbah pertanian, yang pada umumnya menggunakan jerami padi kering dengan cara penambahan bahan kimia berupa $\mathrm{NaOH}, \mathrm{KOH}$, atau urea. Urea berfungsi untuk meningkatkan daya cerna bahan organik dan meningkatkan daya konsumsi.

Adapun beberapa manfaat penggunaan amoniasi jerami bagi ternak adalah sebagai berikut: 1. Menambah ketersediaan bahan pakan; 2. Mencegah kekurangan pakan khususnya pada musim kemarau; 3. Produktivitas ternak akan meningkat; 4. Mengurangi pencemaran. Jerami padi yang diamoniasi mengurangi pembakaran jerami yang tidak dimanfaatkan, sehingga mengurangi pencemaran lingkungan.

\section{Demonstrasi}

Demonstrasi pembuatan amoniasi jerami padi dilaksanakan setelah dilakukannya ceramah dan sesi tanya jawab. Demonstrasi ini diikuti oleh seluruh anggota kelompok tani mitra dan mahasiswa peternakan Universitas Nahdlatul Ulama Purwokerto.

Amoniasi jerami padi berlangsung selama 21 hari. Setelah 21 hari plastik pembukus amoniasi padi dibuka. Amoniasi jerami padi yang dilakukan relatif berhasil karena memiliki bau yang khas dimana bau tersebut dapat meningkatkan palatabilitas daripada ternak sapi. Cara pemberian pakan jerami amoniasi adalah dengan mencampurkan dengan rumput, dan jumlahnya semakin hari semakin menggantikan rumput, sampai pada ahkirnya mampu menggantikan 100\% rumput (Definiati, 2017).

Penyuluhan dan demonstrasi ini diikuti dengan sangat antusias oleh anggota kelompok tani Terus Jaya, karena mereka merasa terbantu dalam menangani masalah pakan ternak dan sudah mendapatkan ilmu serta teknologi tentang pembuatan amoniasi jerami.

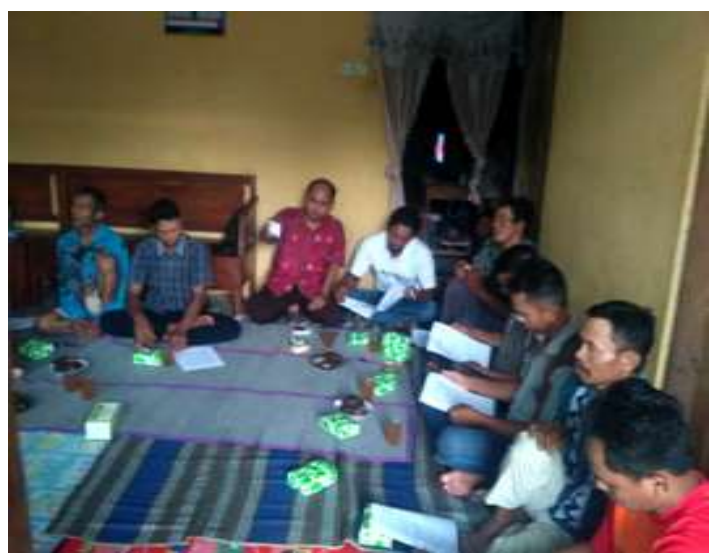

Gambar 2. Pemaparan Materi

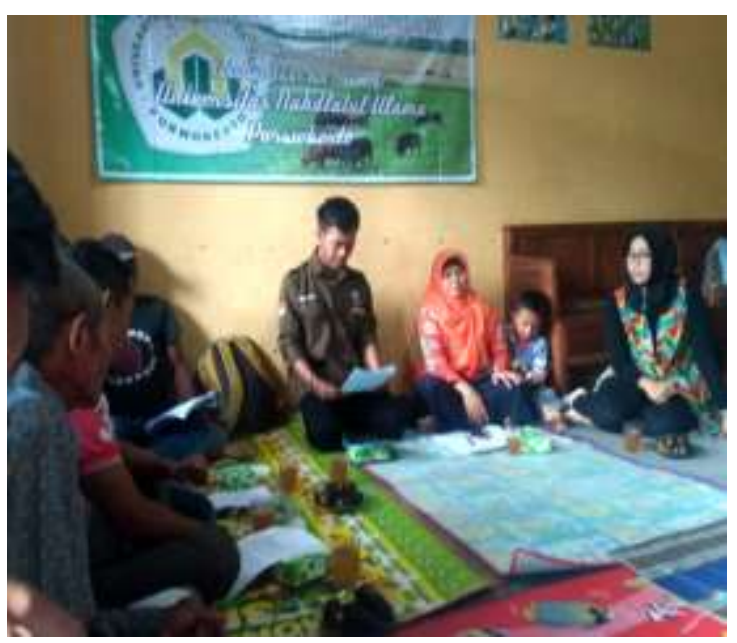

Gambar 3. Mahasiswa ikut dalam pemaparan materi 


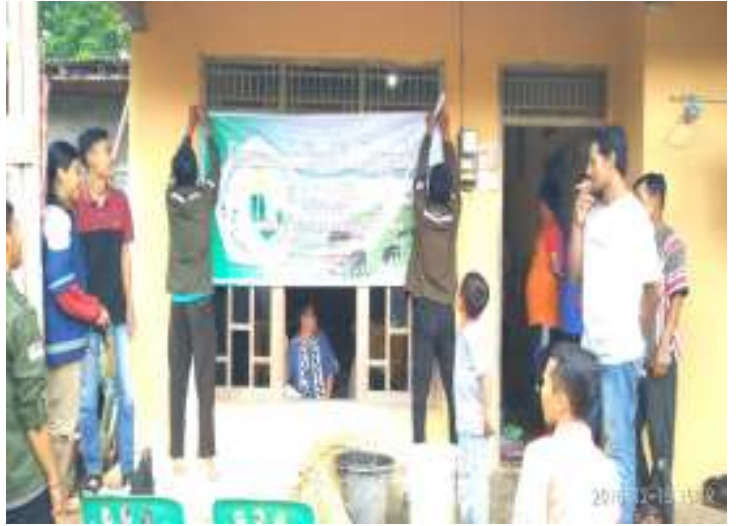

Gambar 4. Persiapan Pelaksanaan

Demonstrasi

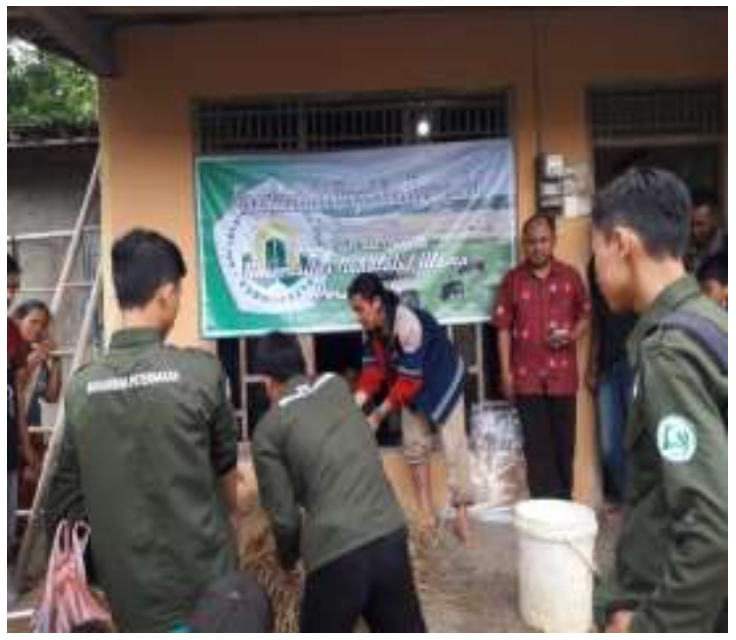

Gambar 5. Demonstrasi Pembuatan Amoniasi Jerami (1)

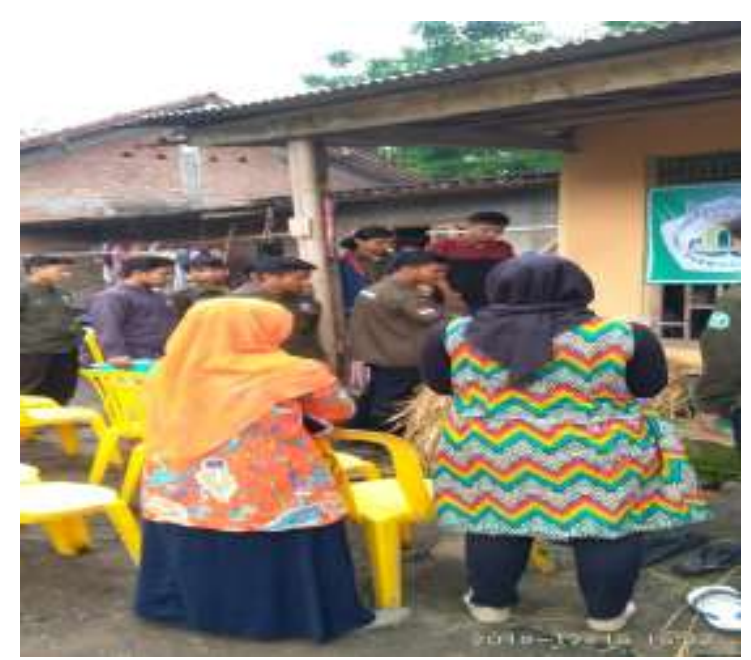

Gambar 6. Demonstrasi Pembuatan Amoniasi Jerami (2)

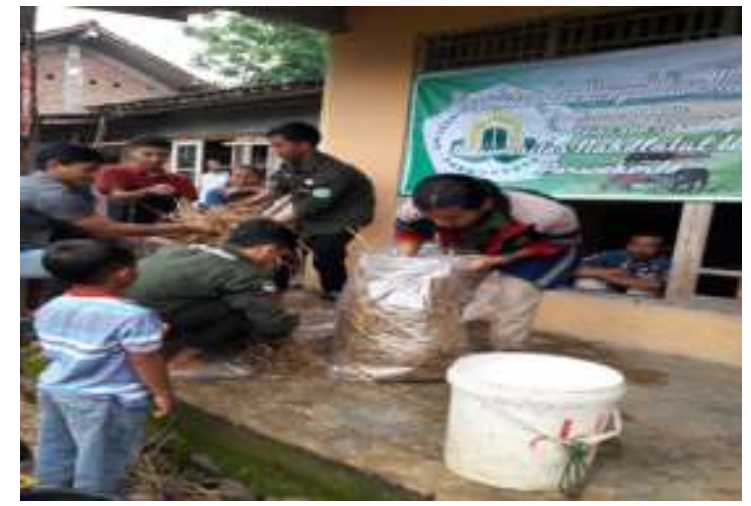

Gambar 7. Demonstrasi Pembuatan Amoniasi Jerami Padi (3)

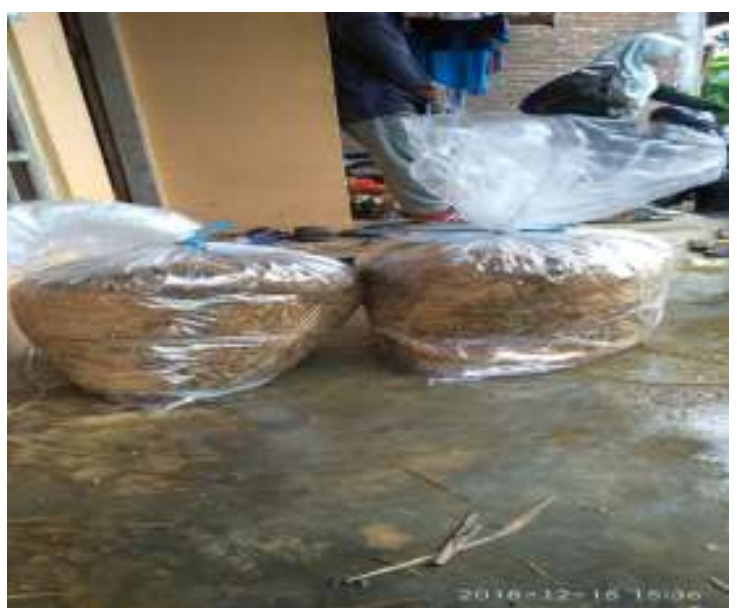

Gambar 8. Amoniasi jerami padi yang sudah jadi

\section{Penutup}

\section{Simpulan}

Penyuluhan mengenai amoniasi jerami padi pada kelompok tani Terus Jaya, Dusun Cunil, Desa Pegalongan, Kecamatan Patikraja Kabupaten Banyumas, dapat diterima dengan baik oleh anggota kelompok tani dan untuk ternak sapi yang diberi amoniasi jerami mau mengkonsumsi amoniasi jerami padi tersebut. Amoniasi jerami padi menjadi alternatif pemberian pakan pada ternak sapi karena ketika musim kemarau susah untuk mendapatkan pakan hijauan.

\section{Saran}

Kelompok tani dapat memanfaatkan jerami padi yang melimpah sebagai 
sumber pakan alternatif yang berkesinambungan karena bahan baku yang melimpah.

\section{Daftar Pustaka}

Definiati, N. (2017). PENGOLAHAN JERAMI PADI SEBAGAI PAKAN TERNAK SAPI PADA KELOMPOK TANI SIDO URIP DESA SRIKUNCORO. Research Report, 693-699.

Kleden, M. M., \& Nenobais, M. (2018). Upaya Pendayagunaan Limbah Pertanian sebagai Pakan Unggulan Musim Kemarau di Lahan Kering. JPM (Jurnal Pemberdayaan Masyarakat), 3(1), 213-221.

Sriyani, N. P., Ariana, N., Oka, A., \& Utami, I. (2016). PELATIHAN TEKNOLOGI JERAMI AMONIASI UNTUK PAKAN TERNAK SAPI BALI DALAM RANGKA MENDUKUNG PROGRAM SIMANTRI PADA KELOMPOK TERNAK "WIDHYA SEMESTI" DESA ANTURAN-BULELENG. Buletin Udayana Mengabdi, 15(3), 15.

SUGAMA, I. N., \& BUDIARI, N. L. G. (2012). Pemanfaatan jerami padi sebagai pakan alternatif untuk sapi Bali dara. Majalah Ilmiah Peternakan.

Suyitno, M. (2006). AMONIASI JERAMI

PADI KERING SEBAGAI

PAKANALTERNATIF TERNAK

SAPI PADA MUSIM

KEMARAUDI KABUPATEN

GUNUNGKIDUL. Pelita-Jurnal

Penelitian Mahasiswa UNY, 1(2). 